Journal of Social Sciences 6 (3): 356-360, 2010

ISSN 1549-3652

(C) 2010 Science Publications

\title{
Producing Television Agriculture Program: Issues and Problems among Malaysian Television Producers
}

\author{
Md. Salleh Hassan, Hayrol Azril Mohamed Shaffril, Bahaman Abu Samah, \\ Mohamad Sham Shahkat Ali and Nor Sabila Ramli \\ Laboratory of Rural Advancement and Agriculture Extension, \\ Institute for Social Science Studies, University Putra Malaysia, Malaysia
}

\begin{abstract}
Problem statement: One of the developing sectors in Malaysia is agriculture. Agriculture doubtlessly has assisted this country in terms of enhancing the economic level, offering a huge number of employment opportunities and uplifting the socio-economy status of the community. To ensure the sustainability of this sector to the country, we must ensure that the valuable agriculture information is continuously provided to the public and the information must be disseminated through the most effective channel. Here, television can be the mean channel. Approach: This study aimed to investigate the issues raised and problems faced by the Malaysian agriculture television program producers in producing the television agriculture programs. Data was collected using an in-depth interview among three agriculture television producers in Malaysia. The questions served as a guide, but allowed respondents freedom and flexibility in their answers. The findings were in the form of descriptive analysis. Results: Based on the analysis done, it can be concluded that the cooperation between Radio Television Malaysia and Department of Agriculture Malaysia is important to ensure the success and continuity of the agriculture programs. It was found that the agriculture programs were evaluated internally by the Radio Television Malaysia auditor and externally by AGB Nielsen. The producers also received feedback from their local and foreign audience in the form of e-mail and telephone. Human resource, transportation and financial are the main problems that need to be overcome by the producers. Conclusion/Recommendations: It is suggested that other media organizations and giant agriculture companies can join RTM in producing agriculture programs. This can aid RTM in producing more innovative agriculture programs and can attract the youth to watch the program.
\end{abstract}

Key words: Television producers, agriculture information, Radio Television Malaysia

\section{INTRODUCTION}

Agriculture is a developing sector in Malaysia. It is expected that during the Ninth Malaysia Plan, this sector will become one of the main income generators in Malaysia. During the Eight Malaysia Plan (RMK-8), the agriculture added-value grew at an average of 3.0\% per annum during the plan period, higher than the previous target which is $2.0 \%$ per annum. The main cause of this is due to a significant performance recorded by the agriculture industrial commodities subsector such as oil palm and rubber. The growth value proves that agriculture in Malaysia has the potential in strengthening the economy of the country and doubtlessly it has the ability in enhancing farmers level of socio-economy. To further enhance this industry's potential and ability, it is important to ensure that the benefited party which is the farmers are provided with all the current and updated agriculture information such as new technologies, new products, methods of marketing, new fertilizers and many more. To provide them with the current and updated information, the related agriculture agencies must use suitable channel to ensure that the message will be accepted and comprehended by the target groups. Television can be the best channel for agriculture information dissemination. Previous studies have already proved that television is the main information sources for the farmers (Khan et al., 2010; Irfan et al., 2006; Md. Sallah and Hayrol Azril, 2009). The dissemination power that television has cannot be denied. The television message can be disseminated in a very short time reaching a big number of audience. Supposedly, television can be used wisely to

Corresponding Author: Md. Salleh Hassan, Laboratory of Rural Advancement and Agriculture Extension, Institute for Social Science Studies, University Putra Malaysia, Malaysia 
disseminate agriculture information to the public especially farmers, but before this type of program is to be produced, there must be issues and problems that must be faced and the answer for this query has become the main objective of this study which is to know the issues and problems in producing agriculture television program among Malaysian television producers.

Before we go to the main objective of this study, it is better for us to get a clear picture about the television industry and television agriculture programs in Malaysia. Currently, there are three media owners that own more than one hundred television channels in Malaysia, namely Radio Television Malaysia (RTM), Media Prima and ASTRO. RTM is owned by the government and have two television channels which are TV1 and TV2. RTM is the earliest media organization in Malaysia and it has provided services for more than 64 years to the public in Malaysia. RTM has planned to introduce over 20 digital channels for free in the future through RTMi. This digitization strategy is in line with other ASEAN countries that have chosen DVB-T as the digital television broadcasting standard and expected to dispose of the full analog broadcasting by 2015. Along with RTM is Media Prima which has started with a television channel known as TV3 in 1984. Currently Media Prima owns four local television channels namely TV3, NTV7, TV8 and TV9 and two overseas television channels namely TV5 Philippines and TV5 Ghana. It also owns three radio stations and four daily newspapers. Astro is the first paid satellite channel in Malaysia. Currently, Astro is offering 82 channels in multilingual languages covering programs in sports, entertainment, news, documentaries and many more.

Evolution of television agriculture programs in Malaysia: History had proved that the government with their full effort had utilized the media in disseminating the valuable and useful information to the public. Previously, broadcasting media in Malaysia through rural broadcasting service has produced special edition related to agriculture as one of the efforts to develop the country which by that time just gained its' independence. Md. Sallah and Musa (2007), has clarify the development of rural broadcasting initiated by Radio Television Malaysia (RTM). It fulfilled the demand of agriculture community and public on agriculture information by that time. Rural broadcasting started in 1948-1960, by that time it acted as an impetus for the government to fight against communist. In that period, special service known as Emergency Division had been established to produce a special program for rural community to fight against communist propaganda. This service then was changed to community and rural broadcasting services. The main objective of this program is to connect the government with the rural community including farmers, mine workers and laborers in rubber plantations as well as providing them with information and entertainment. Radio sets were distributed to the community especially in sensitive areas such as the placement of the new villages for the Chinese and people from the rubber plantations located in rural areas. Md. Sallah and Musa (2007) have informed that the two most successful programs by that time were Progress of the Village (produced three times a week) and Agriculture Digest (produced once a week). The other successful program was a dramatized series known as Kebun Pak Awang. This program managed to be aired for 10 years and managed to attract listeners among rich and poor people, rural and urban people and old and young people. In the period of 1970-1990, Radio Television Malaysia has devoted a huge effort and time to produce quality agriculture television programs such as Dawn of Hope, Light of Development, Success, A Step Forward, Dawn in Bejeweled Land, Era of Success and Agriculture Future.

\section{MATERIALS AND METHODS}

The research approach for this study was a qualitative case study that provided an in-depth description of issues and problems in producing agriculture television programs in Malaysia. Data was collected using an in-depth interview among the agriculture television producer in Malaysia. The indepth interview was conducted among three agriculture television agriculture programs producers in Malaysia. The questions served as a guide, but allowed respondents freedom and flexibility in their answers. The findings were presented in the form of descriptive analysis.

\section{RESULTS}

RTM has never stopped in providing agriculture information to the public. Currently, there are three agriculture programs produced by Unit of Documentary and Magazine of RTM through its two television channels, TV1 and TV2 (Table 1). Previously, Media Prima through its television channel, NTV7, has produced an agriculture television program known as Seed. Another agriculture program known as Agro Asian aired on RTM was stopped at the end of 2009 due to financial problem. The descriptions of the three agriculture programs are as below.

Agro Tech: Agro Tech is produced in a form of magazine. It has three segments which cover profile, research and development and also technology. 


\section{J. Social Sci., 6 (3): 356-360, 2010}

Table 1: Agriculture television program information

\begin{tabular}{lllll}
\hline Agriculture programs & Day & Time & Duration & Channels \\
\hline Agro Tech & Saturday & $6.30 \mathrm{pm}$ & $30 \mathrm{~min}$ & TV1 \\
Agro Journal & Sunday & $6.30 \mathrm{pm}$ & $30 \mathrm{~min}$ & TV1 \\
Our Earth & No specific day, act as & No specific time, act as & Based on the & TV1 and TV2 \\
& filler to fill the time gap & filler to fill the time gap exist & requirements & \\
& exist between two television programs & between two television programs & & \\
\hline
\end{tabular}

The program is hosted by a host or interviewer at a selected location. There is no rigid format for each episode. It depends on suitability, current situation and the program demands. This program can be a catalyst in assisting the agriculture community in enhancing their productivity, skill and information. The Agro Tech producer clarifies the three segments this program has by stating:

"It has three segments, the profile segments usually focus on agency, individual or product, that is profile. Then we have technology segment and then we have R\&D segment. In the $R \& D$ segment, there are $R \& D$ which is still in progress, in the process of technology transfer, for example from the higher learning institution to the consumer, but once the R\&D has been applied, we call it as technology, but not all can be included under the technology segment, we also consider its' suitability for the program"

Agro Journal: Agro Journal is produced in a form of documentary. It focuses on current issue concerning farmers, fishermen, small medium entrepreneurs and commodity industry. Each of the produced issues will be presented educationally and annalistically. One of the main purposes of this program is to fulfill the social obligation in driving the public to involve in agriculture industry in Malaysia. Agro Journal is hoped to raise consciousness among the audiences in Malaysia especially on issues related to agriculture. This is in line with MAAI slogan "agriculture is a business". The producers of Agro Journal stated:

"Agro Journal tries to focus on specific issue, we try to focus on issues, on any problem. For example issue on cabbage clear. That is an issue, right? So we try to focus on it. It takes three months before we can complete the process on this cabbage issue. Frequently, I talk with my researcher, we try to find an issue that we can point to Agro Journal and this Agro Journal program is explained annalistically. The issue must be very deep. Agro Journal can be considered as a heavy program"
Our earth: Our Earth is produced in a form of filler. The main objective of this program is to fill up the time gap that exists between two programs aired in RTM. The content program of our earth is a summarization made from either Agro Journal or Agro Tech. Our Earth producer has emphasized on this program role in filling the time gap exist by stating:

"The air time is not specifically established, it simply fill the time gap that exist if there are television programs ended earlier or a program that cannot be on air so Our Earth will replace the program. Our Earth is available every day; it will be frequently on air"

Agro Asian: After the agriculture program known as Agro ASEAN has finished all of its shooting in the ASEAN countries, a program called Agro Asian was produced. Asian countries such as Korea, Taiwan and China were selected due to higher and advanced agriculture technology that these countries have. Information such as new technology, work culture, spirit and hard work among the farmers from these three countries are exposed to the local farmers. Agro Asian is hoped in helping the government in elevating agriculture sector in line with the goals and aspirations of the government in developing agriculture and creates it as the engine of income for the country. However, Agro Asian has been stopped in 2009. One of the producers informed about the cause of Agro Asian has been stopped:

"It is due to budget, usually this program is continued, but what I heard the budget that is allocated for us is limited. I have met with our head of department and asked her on this program. She replied, it depends on how we make the proposal. The budget for this program is expensive, it is too costly"

Producing agriculture television programs in Malaysia: All the producers agreed that the main objectives of their programs are to educate and inform the farmers regarding new technologies and products, recent agriculture issues and the story of success of other entrepreneurs. The producers get their agriculture 
information sources from related government agencies, researchers, agro-entrepreneurs personal contacts and the public. The roles of agriculture agencies in Malaysia such as Department of Agriculture (DOA), Malaysia Agriculture Research and Development Institute (MARDI), Federal Agriculture Marketing Authority (FAMA), Farmers Authority Organization (FAO) and University Putra Malaysia (UPM) are important to ensure that the content of the program to be produced by RTM have a high quality. Annually, representatives from all agriculture related agencies in Malaysia will be invited in a meeting held by RTM. The main purpose of this meeting is to share ideas between RTM and the agriculture agencies. The agencies will inform RTM about their latest technologies and products and also successful entrepreneurs. Based on this RTM will gain sources to produce the programs. Besides the agriculture agencies, the producers will hire a researcher. This researcher is responsible in giving suggestions on what to be produced and getting the updated agriculture information. Sometimes, agro-entrepreneurs and the public will contact the producers to recommend their new products and successful entrepreneurs at their places.

The air time for all of these programs according to the producers is suitable. But once, the audience rating had significantly increased when one of the programs was aired during the prime time, which was at $9.00 \mathrm{pm}$. the current air time of the programs are $6.30 \mathrm{pm}$ on Sunday and Saturday. The duration of the air time which is $30 \mathrm{~min}$ is suitable, they claimed that if the programs are run for more than $30 \mathrm{~min}$, the viewers will become bored and lose their focus. The time given to them in completing the programs starting from shooting to the editing process according to the producers is enough. Interestingly, it was informed that some of the episodes of the programs were narrated in English in order to attract non-Malay audience and previously Oladele (2006) in his study has emphasized that a program produced in multilingual language will have more potential to attract viewers. The programs will get their ranking based on the internal evaluation done by RTM auditor and external evaluation by AGB Nielsen. Agro Tech is the best rank agriculture program in RTM based on the internal and external evaluation. In terms of feedback, producers do received feedback from their viewers. Interestingly, they also receive feedback from their viewers in Singapore and Brunei. They received feedback in the form of e-mail and telephone. One of the producers has developed a computer database of all the entrepreneurs they have contacted and the feedback they got. The database included information regarding the person and agro-entrepreneurs contact numbers and types of agro-business that they have conducted.

The producers problems in producing television agriculture programs: The financial factors play a significant role in ensuring the continuity of the programs. This can be proved when one of the programs was stopped because of new financial budget imposed by the government on all the government agencies and departments. All of the agriculture programs were given funding by the government and in 2010 there are still no private companies that come forward to provide RTM with sponsorship to produce agriculture television programs.

In terms of human resource, generally all the producers agreed that they have inadequate number of staff, in some cases, the experienced assistant producers are asked to produce the agriculture programs. Besides, they are also asked to produce program other than their actual programs. Transportation is one of the major problems that always occur, especially when it is needed for the shooting processes. Delayed information regarding departure time to the shooting places is the major contributor of this problem.

\section{DISCUSSION}

The main things to be considered in producing television agriculture programs are the suitable air time and financial factor. These two factors without doubt will be the main key in ensuring the continuity of television agriculture programs. This is important as Adeniyi and Bello (2000) previously have emphasized that mass media can be the key of development and agriculture is one of the benefited parties. Other media organizations, especially Media Prima and Astro can follow the steps of RTM in producing agriculture programs. The popularity that these two organizations have can be an advantage for agriculture information to be disseminated to a bigger number of audiences. These two organizations involvement is important as the lack of agriculture information supports resulted in lack of agriculture information development and technology diffusion among the farmers (Demiryurek et al., 2008). They are hoping that these programs can aid the government in attracting more publics especially the youth to be part of the agriculture community in Malaysia.

\section{CONCLUSION}

Based on the results gained it can be concluded that the cooperation between RTM and the government 
agriculture agencies is one of the key factors in ensuring the continuity of the agriculture programs in Malaysia. RTM as one of the main media organizations in Malaysia should be praised for their continuous effort in assisting the development of agriculture sector in Malaysia. However, other media channels and agriculture companies should join the cooperation between RTM and government agriculture agencies. The popularity of some of the giant media organizations in Malaysia such as Media Prima and Astro for example can help in attracting more youth to be part of the agriculture community while the financial power that giant agriculture companies have can help to overcome the financial problems and lack of agriculture programs in Malaysia.

\section{REFERENCES}

Adeniyi, H. and R. Bello, 2006. Nigerian Media, Indigenous Languages and Sustainable Development. In: Shifting the Center of Africanism in Language Politics and Economic Globalization, Arasanyin, O.F. and M.A. Pemberton, (Eds.). LINGREF, Somerville, MA, USA, pp: 155-160. http://www.lingref.com/cpp/acal/36/paper1419.pdf

Demiryurek, K., H. Erdem, V. Ceyhan, S. Atasever and O. Uysal, 2008. Agricultural information systems and communication networks: The case of dairy farmers in Samsun province of Turkey. Inform. Res., 13: 343-343. http://InformationR.net/ir/132/paper343.html
Irfan, M., M. Sher, A.K. Ghanzafar and M. Asif, 2006. Role of mass media in disseminating agriculture technologies among farmers. Int. J. Agric. Biol., 8: 417-419.

Khan, G.A., S. Muhammad, K.M. Chaudry and M.A. Khan, 2010. Present status and future preference of electronic media as agricultural information sources by the farmers. Pak. J. Agric. Sci., 47: 166-172.

Md. Sallah, H. and A.H. Musa, 2007. Agricultural communication. Proceeding of the 50 Years of Malaysian Agriculture (MA'07), UPM Publisher, Serdang, Selangor, pp: 729-741.

Md. Sallah, H. and M.S. Hayrol Azril, 2009. Internet usage among agro-based entrepreneurs: Can it affects productivity. J. Agric. Soc. Sci., 5: 61-66. http://www.fspublishers.org/jass/pastissues/JASSVOL_5_NO_3/2.pdf

Oladele, O.I., 2006. Multilinguality of farm broadcast and agriculture information access in Nigeria. Nordic J. Afr. Stud., 15: 199-205. http://www.njas.helsinki.fi/pdffiles/vol15num2/oladele5.pdf 